FKIP Universitas Kuningan

\title{
PENERAPAN MODEL TUTORIAL UNTUK MENINGKATKAN KEMAMPUAN SISWA DALAM MENULIS SURAT DINAS
}

\author{
Agi Ahmad Ginanjar \\ Jurusan Pendidikan Bahasa Indonesia \\ Fakultas Keguruan dan Ilmu Pendidikan Universitas Siliwangi \\ agiahmad@unsil.ac.id
}

\begin{abstract}
ABSTRAK: Penelitian ini bertujuan untuk mengetahui berhasil tidaknya model pembelajaran tutorial meningkatkan kemampuan pada siswa kelas VIII SMP Negeri 1 Puspahiang. Metode Penelitian ini adalah metode tidakan kelas. Sedangkan teknik penelitiannya adalah (1) teknik wawancara, (2) teknik observasi, (3) teknik tes. Sumber data penelitian ini ada dua yaitu sumber primer dan sumber sekunder. Sumber data primer adalah siswa kelas VIII A SMP Negeri 1 Puspahiang.. Sedangkan sumber data sekunder adalah guru, dokumen kelas, dan kepala sekolah. Hasil observasi dan analisi data menunjukkan bahwa kemampaun siswa kelas VIII A SMPN 1 Pusphiang dari siklus I ke siklus II mengalami peningkatan. Hal ini dapat diketahui dari hasil oleh data bahwa rata-rata pelaksanaan pembelajaran tutrial siklus I hanya 75\% sementara siklus II 95,8\%. Selain itu, sikap siswa ketika mengikuti pembelajaran dari siklus I ke siklus II mengalami peningkatan. Peningkatan tersebuut ditunjukkan bawah pada siklus I hanya satu kategori yang sangat baik yanitu kerja sama, sedangkan keaktifan, keseungguhan, dan pasrtipasi kategorinya baik. Pada siklus II semua aspek yang diamati baik kerja sama, keaktifan, kesungguhan, dan partispasi semuanya berkategori sangat baik. Nilai hasil belajar siswa dalam menulis surat dinas juga mengamali peningkatan dari siklus I ke siklus II. Pada siklus I sebanyak 12 siswa kategori sangat baik, dan 11 siswa kategori baik, dan 8 orang kategiri cukup. Pada siklus II meimgkat menjadi 24 sisa kategori sangat baik dan 7 siswa dengan kategori baik. Dengan demikian hipotesis dalam penelitian ini diterima. Artinya, model tutorial meningkatkan hasil pembelajaran menulis surat dinas pada siswa kelas VIII A SMP Negeri 1 Puspahiang.

KATA KUNCI: Menulis; Surat dinas; Tutorial.

\section{THE IMPLEMENTATION OF TUTORIAL METHOD TO IMPROVE STUDENT'S ABILITY} IN WRITING FORMAL LETTER
\end{abstract}

\begin{abstract}
This study aims to determine the success or failure of the tutorial learning model in improving the abilities of grade VIII students of SMP Negeri 1 Puspahiang. This research method is a class action method. While the research techniques are (1) interview techniques, (2) observation techniques, (3) test techniques. There are two sources of data in this study, namely primary sources and secondary sources. Primary data sources were students of class VIII A SMP Negeri 1 Puspahiang. Meanwhile, secondary data sources were teachers, class documents, and school principals. The results of observation and data analysis showed that the ability of class VIII A students of SMPN 1 Pusphiang from cycle I to cycle II had increased. It can be seen from the results by the data that the average implementation of tutrial learning in cycle I is only $75 \%$ while cycle II is $95.8 \%$. In addition, students' attitudes when participating in learning from cycle I to cycle II have increased. This improvement is shown below in cycle I, there is only one very good category, namely cooperation, while activeness, sincerity, and participation are good categories. In cycle II, all aspects observed, both cooperation, activeness, seriousness, and participation, were all in very good categories. The value of student learning outcomes in writing official letters also increased from cycle I to cycle II. In the first cycle there were 12 students in very good category, and 11 students in good category, and 8 students in enough category. In the second cycle it increased to 24 remaining in very good categories and 7 students with good categories. Thus the hypothesis in this study is accepted. That is, the tutorial model improves the learning outcomes of writing official letters for class VIII A students of SMP Negeri 1 Puspahiang.
\end{abstract}

KEY WORDS: Write; Official letter; Tutorial

\begin{tabular}{llll}
\hline Diterima: & Direvisi: & Distujui: & Dipublikasi: \\
03-10-2020 & 06-10-2020 & $06-10-2020$ & $28-10-2020$
\end{tabular}

Pustaka : Ginanjar, A. A. (2020). Penerapan Model Tutorial Untuk Meningkatkan Kemampuan Siswa Dalam Menulis Surat Dinas. Fon : Jurnal Pendidikan Bahasa dan Sastra Indonesia, 16(2), 134-144. 


\section{PENDAHULUAN}

Dalam kehidupan sehari-hari, manusia tidak lepas dari kegiatan . Komunikasi langsung dilakukan dengan cara berbicara langsung dengan lawan bicara. Sedangkan komunikasi tidak langsung dilakukan dengan cara tidak berbicara langsung dengan lawan bicara. Salah satu alat yang digunakan untuk berkomunikasi secara tidak langsung dengan menggunakan kertas adalah surat. Menurut Subagio dalam Abidin (2006, hlm. 173), "Surat adalah alat komunikasi yang mempergunakan bahasa tulis di atas kertas yang sangat erat hubungannya dengan kehidupan manusia." Lebih lanjut Kosasih (2003, hlm. 11) menyatakan, "Surat adalah media komunikasi tertulis antara seseoang atau lembaga dengan seseorang atau lembaga lainnya."

Surat terdiri atas beberapa jenis, salah satunya adalah surat dinas. Surat dinas ini merupakan surat yang dikeluarkan oleh suatu organisasi/instansi dalam melakukan komunikasi dengan lembaga lain (Kemal, 2013). Marjo (2005, hlm. 209) menyatakan, "Surat jabatan atau surat dinas merupakan surat resmi yang di dalamnya menyangkut berbagai hal tentang kedinasan." Lebih lanjut Sabariyanto (1998, hlm. 27) menyatakan, "Sebenarnya surat dinas berbeda dengan surat resmi, tetapi karena sebagian besar surat dinas bersifat resmi, surat dinas disamakan dengan surat resmi."

Surat dinas ini diberikan kepada organisasi/instansi terkait dengan tujuan memberitahukan, mengumumkan, memberikan pernyataan dan lain-lain. Selain menyampaikan informasi kepada pihak yang dituju, surat dinas juga menjadi duta atau perwakilan suatu instansi yang mengirimkannya. Sebagai bentuk dokumentasi yang otentik, surat dinas sangat mungkin dibaca oleh orang, komunikasi, baik komunikasi secara langsung maupun tidak langsung diperbanyak, dan disimpan dalam jangka waktu yang lama untuk suatu ketika dilihat kembali. Oleh karena itu, bentuk, isi dan bahasa sebuah surat dinas menjadi suatu hal yang perlu diperhatikan.

Menyusun surat dinas yang baik tidaklah mudah. Sebagai bentuk komunikasi tulis, surat tidak saja menuntut penggunaan bahasa yang benar tetapi juga harus jelas, efektif, dan mampu mengungkapkan maksud yang ingin disampaikan oleh instansi/perusahaan pengirimnya. Oleh karena itu, surat dinas menjadi hal yang sangat penting untuk dipelajari. Dalam kurikulum di sekolah kemampuan menulis surat dinas menjadi salah satu kompetensi dasar yang harus dikuasai siswa. Akan tetapi, kenyataan di lapangan masih ada siswa yang belum mampu menulis surat dinas dengan benar. Kesalahan meraka dalam menulis surat dinas di antaranya: keasalahan dalam menggunakan bahasa yang tidak benar, ejaan yang tidak tepat, dan penggunaan kalimat yang belum efektif. Hal ini penulis peroleh ketika melakukan observasi ke SMPN 1 Puspahiang. Berdasarkan hasil observasi tersebut diperoleh informasi bahwa kekurangmampuan siswa dalam menulis surat dinas disebabkan oleh kurangnya pemahaman siswa tentang penulisan surat dinas. Hal ini disebabkan karena ketika proses pembelajaran siswa tidak aktif dan kurang sungguh-sungguh. Hal ini ditunjukkan dengan sikap siswa masih banyak yang ragu dan segan untuk bertanya kepada guru tentang hal yang tidak mereka pahami dalam menulis surat dinas sekalipun guru sudah memberikan kesempatan kepada siswa untuk bertanya. Kondisi pembelajaran dengan siswa yang hanya menyimak apa yang disampaikan 
guru tanpa aktif untuk mengajukkan pertanyaan atas apa yang tidak dimengertinya hal tersebut mengakibatkan pembelajarn belum berhasil.

Berdasarkan uraian di atas, penulis tertarik melakukan upaya untuk meminimalkan permasalahan tersebut. Dengan memperhatikan faktor penyebab ketidakmampuan mahasiswa tersebut. Penulis memandang perlu adanya suatu model pembelajaran yang dapat meningkatkan keaktifan dan kesungguhan siswa dalam melakukan pembelajaran. Model pembelajaran yang penulis pilih untuk mengatasi faktor penyebab ketidakmampuan siswa adalah model pembelajaran tutorial. Winataputra (1997, hlm. 205) menyatakan, "Model tutorial merupakan teknik pembelajaran yang diartikan sebagai bimbingan dan bantuan belajar". Dalam pelaksanaannya pembelajaran dengan tutorial ini memberikan bimbingan dan bantuan belajar kepada siswa baik oleh guru maupun oleh sesama siswa yang kemampuannya di atas siswa yang lain. Dengan adanya model pembelajaran dengan tutor sebaya atau sesama temannya keraguan dan keseganan siswa untuk bertanya tentang apa yang belum mereka pahami dapat diatasi dengan baik karena mereka belajar dengan temannya sendiri dan guru membimbing semua proses itu.

Lebih lanjut Winataputra (1997, hlm. 205) menyatakan

Model tutorial merupakan kerangka prosedural pembelajaran yang menitikberatkan pada pemberian bimbingan dan bantuan belajar oleh pengajar atau sesama siswa. Bimbingan dan bantuan dimaksudkan agar satu sama lain dapat saling memberikan stimulus (pemicu) dan saling meningkatkan inetnsitas belajar (memacu). Model tutorial dapat menciptakan suasana belajar jauh lebih demokratis dan lebih dinamis. Tutor bukanlah semata-mata sebagai sosok figur guru tetapi juga sebagi sosok teman belajar.
Selain itu, penulis memilih model tutorial karena tutorial bertitik tolak dari prinsip yang diperkenalkan John Amos Comenius, "He who teaches others teaches himself" (Siapa mengajar yang lain ia mengajar dirinya sendiri). Belajar dengan tutorial ternyata lebih meningkatkan penguasaan bahan lebih demokratis dan memberi keuntungan kepada kedua belah pihak tutor dan tutee (tutor dan yang ditutori) (Winataputra, 1997). lebih lanjut Ehli dan Larsen dalam Winataputra (1997: hlm. 206) menyatakan bahwa berbagai penelitian menunjukkan bahwa tutorial merupakan bentuk bimbingan belajar yang mampu menciptakan situasi belajar yang kondusif bagi peningkatan penguasaan materi melalui proses pengkajian.

Salah satunya hasil penelitian Anggorowati yang menerapkan pembelajaran tutor sebaya dalam pembelajaran sosiologi yang menyatakan bahwa pada pelaksanaan model tutor sebaya kegiiatan pembelajaran menjadi lebih aktif atau hidup terlihat dengan banyaknya siswa yang menanggapi permasalahan yang sedang dibicarakan dan siswa juga tidak malu-malu menayakan apa yang merka tidak pahami dari guru kepada tutornya (Anggorowati, 2011). Dengan hasil penelitian seperti itu penulis tertarik untuk menerapkan model tutorial dalam mengatasi permasalahan pembelajaran menulis surat dinas .

Dari pernyataan di atas, dapat penulis simpulkan bahwa tujuan yang ingin dicapai dari pembelajaran tutorial ini adalah agar siswa satu sama lain dapat saling memberi stimulus dan saling meningkatkan proses belajar. Selain dapat memberikan stimulus yang akan lebih meningkatkan proses pembelajaran antara tutor dan yang ditutori, pembelajaran dengan model tutorial juga dapat menciptakan suasana belajar jauh lebih dinamis dan demokratis. Hal ini terjadi karena tutor bukanlah semata-mata 
sebagai sosok figur guru tetapi juga sebagai sosok teman belajar. Pembelajaran tutorial tidak menjadikan guru sebagai sosok yang serba tahu yang membuat siswa tidak begitu aktif menjalani proses pembelajaran, melainkan sosok teman belajar yang akan lebih terkesan demokratis dan tidak ada rasa canggung antara guru dengan siswa dan akan memotivasi siswa untuk lebih aktif.

Pada penelitian ini, penulis menggunakan model penelitian tindakan kelas. Penulis memilih model penelitian tindakan kelas, karena penulis beranggapan bahwa kurang berhasilnya pembebelajaran menulis surat disebabkan oleh proses pembelajaran yang kurang optimal. Arikunto (2007: hlm. 2) menyatakan, "Penelitian tindakan kelas bukan sekadar mengajar seperti biasanya, tetapi harus mengandung suatu pengertian, bahwa tindakan yang dilakukan didasarkan atas upaya meningkatkan hasil, yaitu lebih baik dari sebelumnya." Tujuan penelitian ini adalah untuk mengetahui dapat atau tidaknya model pembelajaran tutorial meningkatkan kemampuan siswa dalam menulis surat dinas.

Dengan model tindakan kelas penulis melakukan upaya peningkatan mutu pembelajaran untuk mendapatkan hasil pembelajaran yang lebih baik. Salah satu langkah yang penulis laksanakan dalam melakukan penelitian ini adalah dengan mencoba menerapkan model pembelajaran yang lebih menarik, demokratis, dan dapat memotivasi siswa untuk lebih aktif dalam melaksanakan pembelajaran yaitu pembelajaran dengan model tutorial.

\section{METODE}

Metode yang digunakan dalam penelitian ini adalah penelitian tindakan kelas. Heryadi (2014, hlm. 65) menyatakan, "Penelitian dengan menggunakan metode penelitian tindakan kelas lebih cenderung untuk perbaikan perbaikan proses pembelajaran, namun tidak dapat menghasilkan teori baru.". Dalam penelitian ini terdiri atas dua varibel yaitu model tutorial sebagai variabel bebas dengan variabel terikatnya kemampuan siswa dalam menulis surat dinas. Pengumpulan data dalam penelitian ini dilakukan dengan teknik observasi dan teknik tes.

Untuk memperoleh data yang diperlukan dalam penelitian ini instrument penelitian yang penulis gunakan dalam penelitian ini adalah pedoman wawancara, pedoman observasi, silabus, rencana pelaksanaan pembelajaran, instrumen tes dan kriteria penilaian. Sumber data dalam penelitian ini ada dua yaitu sumber data primer dan sumber data sekunder. Sumber data primer adalah siswa kelas VIII A SMP Negeri 1 Puspahiang sebanyak 31 siswa, sedangkan sumber data sekundernya adalaha guru, dokumen kelas. Model penelitian tindakan kelas yang digunakan dalam penelitian ini yaitu model spiral penelitian tindakan kelas yang dikemukakan Hopkins dalam Arikunto (2007, hlm. 105). "Daur ulang penelitian tindakan diawali dengan perencanaan tindakan (planning), penerapan tindakan (action), imengobservasi dan mengevaluasi proses dan hasil tindakan (observation and evaluation), dan melakukan refleksi (reflecting), dan seterusnya sampai perbaikan atau peningkatan yang diharapkan tercapai (kriteria keberhasilan)". Analisis data penelitian ini melalui langkah-langkah 1) mengklasifikasikan data, 2) mengkoding data, 3) menganalisis dan mempresentasekan, 4) menafsirkan data, 5) menjelaskan juga menyimpulkan.

\section{HASIL DAN PEMBAHASAN}

Penelitian ini dilaksanakan di SMPN 1 Puspahiang. Penelitian ini dilakukan dalam pembelajaran menulis 
surat dinas. Kajian dalam penelitian ini adalah kemampuan siswa dalam menulis surat dinas. Penelitian ini dilakukan dalam tiga tahap yaitu tahap awal, siklus I, dan siklus II. Tahap awal dilakukan untuk mengetahui kekurangan pada proses dan hasil belajar menulis surat dinas. Selain itu dilakukan untuk mengetahui faktor penyebab kurangnya kemampuan siswa.

Hasil dari kegiatan di tahap awal dijadikan dasar untuk melakukan sebuah tindakan untuk memperbaiki proses dan hasil belajar menulis surat dinas di siklus I. Hasil dari proses dan hasil belajar di siklus I dievaluasi dan direfleksi untuk mengetahui kekurangnya dan diperbaiki disiklus II. Setelah dilakukan perbaikan disiklus II kekurangan yang terdapat di siklus I dan tahap awal sudah teratasi sehingga penelitian tidak dilanjutkan ke siklus berikutnya.

\section{Tahap Awal}

Untuk lebih menyakinkan hasil observasi tentang kemampuan siswa dalam menulis surat dinas, pada kegiatan awal pembelajaran penulis melaksanakan kegiatan awal dengan memberi tugas kepada siswa menulis surat dinas perihal permohonan izin kegiatan yang berkenaan dengan kegiatan sekolah dan siswa menulis surat secara perorangan.

Selama siswa melaksanakan tugas yang diberikan, penulis memonitor dan memperhatikan semua kegiatan yang dilakukan siswa. Tampak pada observasi awal siswa belum mengenal benar menulis surat dinas. Ada siswa yang bertanya kepada penulis juga kepada teman-temannya tentang surat dinas. Ada juga yang kebingungan dan ragu-ragu. Banyak siswa yang bertanya dari mana mulai menulis surat dinas dan bagaimana bentuknya. Dari kenyataan seperti itu penulis menyimpulkan memang benar siswa belum mampu menulis surat dinas.

\section{Pembelajaran Siklus I}

persiapan, pelaksanaan, dan review/balikan. Berikut penulis uraikan kegiatan yang dilakukan dalam tiap tahap tersebut.

\section{Persiapan}

Pada tahap ini penulis menyiapkan RPP yang memuat tujuan pembelajaran, isi, dan penilaian. tahap ini disiapkan juga pemeran tutor dan tutee dilengkapi dengan deskripsi tugasnya masing-masing. Tidak lupa juga kelas ditata sesuai kebutuhan tutorial dengan merapatkan meja-meja membentuk kelompok. Menyiapkan aturan main tutorial atau skenario pembelajaran, dan menetapkan topik pembelajaran yaitu menulis surat dinas.

\section{Pelaksanaan Tindakan}

Pelaksanaan tindakan yang penulis lakukan dibagi ke dalam tiga kegiatan: pendahuluan, kegiatan inti, dan penutup. Pada kegiatan pendahuluan pembelajaran diawali dengan apersepsi guna membangung keterkaitan pembelajaran sebelumnya dengan pembelajaran saat ini. Dilanjutkan dengan menyampaikan materi pembelajaran yaitu menulis surat dinas, menyampaikan tujuan pembelajaran, dan menyampaikan skenario pembelajaran model tutorial. Pesereta didik diarahkan untuk membentuk kelompok. Dari setiap kelompok siswa yang dipilih sebagai tutor semua ke depan untuk mendapatkan pengarahan dari penulis dalam melaksanakan tutorial dan masalah yang harus diselesaikan dan didiskusikan dikelompoknya masing-masing.

Setelah kegiatan pendahuluan selesai, peseta didik mengikuti kegiatan inti dengan melaksanakan pembelajaran dengan tutor yang sudah ditentukan. kelompoknya masing-masing para tutor memperkenalkan topik masalah yang harus dipelajari dengan kegiatan tutorial. Permasalahan yang penulis sajikan berupa analisis kesalahan surat dinas dari contoh surat dinas yang telah disediakan. Surat 
dinas yang salah tersebut oleh tutor dibagikan kepada teman kelompoknya sebagai peserta turorial.

Selanjutnya tutor mengarahkan temannya untuk mendata kesalahan yang ada dalam contoh surat tersebut. Tutor memimpin diskusi dan penggalian pendapat dari para peserta di kelompoknya masing-masing. Setiap pendapat yang disampaikan para peserta, tutor berupaya menggali pemikiran dan pemahaman mereka dengan memberikan pertanyaan lanjutan dan menggali argumen-argumen yang mereka pikirkan sehingga pemahaman siswa tentang kesalahan dalam surat dinas itu benarbenar dipahami dan memahami dengan baik surat dinas yang benar. Dalam tahap ini terlihat diskusi-diskusi di setiap kelompok yang dipandu oleh tutor, tampak pada kegiatan ini siswa sudah mulai berani berpendapat dan tidak segan lagi menyampaikan hal-hal yang meraka belum pahami. Ketika berdiskusi tersebut penulis berkeliling ke setiap kelompok untuk memantau jalanya tutorial dan sesekali memberikan bantuan untuk meluruskan arah diskusi jika ada tutor yang meminta bantuan.

Kegiatan berikutnya tutor bersama teman kelompoknya memperbaiki surat dinas yang salah. Selanjutnya perwakilan tiap kelompok, melaporkan hasil kerjanya di depan dan kelompok yang lain memberian tanggapan dari kelompok lain. Pada akhir kegiatan tutor menyimpulkan pokok-pokok permaslahan yang dibahas sehingga terbentuk suatu pemahaman cara penulisan surat dinas yang benar.

\section{Review/Balikan}

Kegiatan review/balikan dilakukan penulis untuk mengajak semua siswa merefleksikan peleksanaan kegiatan tutorial yang telah dilaksanakan. Pada tahap ini penulis memberikan penguatan terhadap kelemahan yang dilakukan para peserta dan pemeran dalam melaksanakan pembelajaran tutorial.
Penulis juga menjelaskan tujuan setiap langkah yang dilaksakan dalam tutorial terhadap kemampuan siswa dalam menulis surat dinas. Dalam kegiatan ini juga penulis mempersiapkan tindak lanjut yang akan dilaksanakan dipertemuan selanjutnya. Setelah proses pembelajaran berakhir penulis menguji kemampuan siswa dalam menulis surat dinas dengan meminta siswa untuk melaksanakan tes menulis surat dinas secara individu.

\section{Hasil Observasi dan Evaluasi \\ Pelaksanaan Pembelajaran Turorial}

Data hasil observasi tentang pelaksanaan pembelajaran tutorial dapat dilihat pada tabel 1 di bawah ini.

Tabel 1. Hasil Observasi Pelaksanaan Pembelajaran Tutorial

\begin{tabular}{cc}
$\begin{array}{c}\text { Penentu } \\
\text { Keberhasilan } \\
\text { Tindaka }\end{array}$ & $\begin{array}{c}\text { Rerata Skor } \\
\text { Pelaksanaan } \\
\text { Pembelajaran }\end{array}$ \\
\hline Langkah 1 & 3 \\
\hline Langkah 2 & 3 \\
\hline Langkah 3 & 3 \\
\hline Rata-Rata & 3 \\
\hline Rata-Rata dalam \% & $75 \%$ \\
\hline
\end{tabular}

Keterangan:

Kriteria presentasi: $80 \%-100 \%=$ sangat baik, $70 \%-79 \%=$ baik, $60 \%-69 \%=$ cukup, $50 \%-59 \%=$ kurang, dan $<50 \%=$ sangat kurang.

Berdasarkan skor data pelaksanaan pembelajaran tutorial diperoleh rata-rata persentase pelaksanaan pembelajaran pada siklus I hanya sebesar $75 \%$. Hal ini disebabkan karena pada setiap tahapan belum maksimal. Pencapaain pelaksanaan yang belum maksimal ini disebabkan karena hal di antaranya: 1) pada tahap persiapan, siswa belum terbiasa melaksanakan pembelajaran dengan model tutorial, penentuan tutor dibutuhkan waktu yang cukup lama karena siswa rata-rata tidak mau menjadi tutor, meskipun penulis memilih berdasarkan perolehan nilai pada pembelajaran sebelumnya, 2) pada kegiatan pelaksanaan tutor yang sudah 
bersedia dalam melaksanakan tugasnya masih terlihat kaku dan ragu, pada tahap diskusi tutor kurang bisa memmpin jalanya diskusi karena terlihat kurang begitu percaya diri sehingga pemahaman siswa belum begitu tergali, pada kegiatan simpulan pokok-pokok masalah yang dilakukan tutor belum memberikan pemahaman terhadap peserta yang ditutori. 3) pada kegiatan penutup review/balikan waktu yang tersisa tidak begitu banyak sehingga refleksi belum menyeluruhan sehingga kelemahaman pelaksanaan pembelajaran tersebut belum terbahas dengan baik.

\section{Proses pembelajaran siswa}

Selama proses pembelajaran penulis juga mengamati perlaku siswa selama mengikuti pembelajaran tersebut. Dari hasil pengamatan terhadap sikap siswa selama mengikuti proses pembelajaran didapatkan data dalam tabel 2 di bawah ini.

Tabel 2. Rata-rata Skor \& Prosentase Hasil Observasi Proses Pembelajaran Siswa

\begin{tabular}{lccc}
\hline $\begin{array}{c}\text { Aspek yang } \\
\text { Diamati }\end{array}$ & Skor & $\begin{array}{c}\text { Prosentase } \\
(\mathbf{\%})\end{array}$ & Kategori \\
\hline Keaktifan & 2,87 & 71,77 & Baik \\
\hline Kerja sama & 3,45 & 86,29 & $\begin{array}{c}\text { Sangat } \\
\text { Baik }\end{array}$ \\
\hline Kesungguhan & 3,13 & 78,23 & Baik \\
\hline Partisipasi & 3,06 & 76,61 & Baik \\
\hline
\end{tabular}
Berdasarkan tabel 2 di atas, diketahui bahwa sikap siswa diamati dalam empat aspek yaitu, keaktifan, kerja sama, kesungguhan, partisipasi. Pada aspek keaktifan diperoleh skor rata-rata 2,87 atau $71,77 \%$ dengan katagori baik. Artinya selama mengikuti pembelajaran dengan tutorial siswa secara keseluruhan sudah menunjukkan keaktifan yang baik. Pada aspek kerja sama diperoleh skor 3,45 atau $86,29 \%$ dengan katagori sangat baik. Artinya dengan pembelajaran tutorial para siswa selama proses pembelajaran bekerja sama dengan sangat baik. Pada aspek kesungguhan diperoleh nilai rata-rata 3,13 atau 78,23\% dengan kategori baik, artinya peseta didik sudah menampakkan sikap kesungguhan selama mengikuti proses pembelajaran. Pada tahap partisipasi diperoleh nilai rata-rata skor 3,06 atau 76,61 dengan kategori baik, artinya partsipasi siswa dalam belajar dengan model tutorial menunjukkan partsipasi yang baik.

\section{Kemampuan menulis surat dinas}

Kemampuan menulis surat dinas dalam penelitian adalah kesanggupan siswa dalam membuat surat dinas sesuai dengan kriteria dan ciri surat dinas yang benar yang meliputi, sistematika surat, Bahasa yang benar, dan tata tulis yang benar. Kemampuan menulis surat dinas ini dilihat dari hasil kerja siswa dalam menulis surat dinas setelah mereka mengikuti pembelajaran dengan model tutorial. Dari hasil analisis data pekerjaaan siswa dalam menulis surat dinas diperoleh data sebagai berikut.

Tabel 3. Nilai Kemampuan Menulis Surat Dinas Siswa pada Siklus I

\begin{tabular}{ccc}
\hline Kategori & $\begin{array}{c}\text { Rentang } \\
\text { Skor }\end{array}$ & $\begin{array}{c}\text { Jumlah } \\
\text { Siswa }\end{array}$ \\
\hline Sangat Baik & $80-100$ & 12 \\
\hline Baik & $70-79$ & 11 \\
\hline Cukup & $60-69$ & 8 \\
\hline Kurang & $50-59$ & 0 \\
\hline Sangat Kurang & $<50$ & 0 \\
\hline Berdasarkan & tabel 3 & di atas,
\end{tabular}

diketahui bahwa siswa yang memperoleh nilai dalam kategori sangat baik sebanyak 12 orang, baik 11 orang, dan cukup 8 orang.

\section{Refleksi}

Berdasarkan data pada kedua tabel di atas, ternyata ada siswa yang sudah mampu menulis surat dinas sesuai dengan kriteria. Surat dinas yang ditulis siswa sudah memenuhi kelengkapan struktur, ketepatan isi, penggunaan bahasa yang baik, dan penggunaan ejaan yang tepat. Namun, ada pula siswa yang belum mampu menulis surat dinas sesuai dengan kriteria. Surat yang ditulis siswa isinya 
kurang tepat, penggunaan bahasa kurang baik, dan peneggunaan ejaan masih belum tepat.

Secara ringkas refleksi dinyatakan sebagai berikut.

1. Siswa sudah ada keinginan untuk bisa menulis surat dinas.

2. Belum semua siswa mampu menulis surat dinas dengan baik.

3. Belum semua siswa menulis surat dinas sesuai dengan kriteria.

Atas dasar refleksi tersebut penulis berkesimpulan bahwa pada kegiatan siklus satu ini, ternyata belum semua siswa mampu menulis surat dinas seuai dengan kriteria, ketepatan isi, penggunaan bahasa yang baku, dan pengguanaan ejaan yang tepat sehingga perlu dilanjutkan pada tindaklan berikutnya.

\section{Pembelajaran pada Siklus II Persiapan}

Pada pelaksanaan tindakan/siklus satu ternyata belum semua siswa mampu menulis surat dinas sesuai dengan kriteria. Dalam menulis surat dinas siswa tidak mempoerhatikan ketepatan isi surat, penggunaan bahasa yang baku, dan penggunaan ejaan yang masih belum tepat. Para siswa masih belum menyadari pentingnya menulis surat dinas yang berkenaan dengan kegiatan sekolah, sehingga dalam menulis surat dinas mereka itu asal-asalan. Sejalan dengan permasalahan tersebut penulis perlu melaksanakan lagi tindakan selanjutnya yaitu siklus dua, dan penulis membuat rencana pemecahannya.

\section{Pelaksanaan Tindakan}

Pada sikuls dua langkah-langkah penelitian yang penulis lakukan sama dengan langkah-langkah penelitian siklus satu yaitu menggunakan model pemebelajaran tutorial. Namun pada pembelajaran siklus dua yang berperan sebagai tutor adalah siswa yang penulis nilai telah mampu menulis surat dengan baik. Sebelum penulis melaksanakan tindakan terelebih dahulu penulis membuat sekenario pembelajaran, menyiapkan media pembelajaran, dan menyiapkan instrumen penelitian. Setelah tahap perencanaan penulis selesai buat, selanjutnya tahap pelaksanaan tindakan. Dalam pelaksanaan tindakan penulis bagi ke dalam tiga tahap kegiatan yaitu kegiatan awal, kegiatan inti, dan kegiatan akhir.

Pada kegiatan awal penulis membagi siswa ke dalam enam kelompok yang masing-masing kelompok beranggotakan lima orang dan satu kelompok enam orang karena jumlah siswanya ganjil yaitu 31 orang. Setelah siswa terbagi ke dalam kelompok, selanjutnya penulis melakukan apersepsi dan dilanjutkan dengan memberikan beberapa pertanyaan tentang surat dinas untuk menggali pengetahuan siswa tentang surat dinas dan ini merupakan pretes bagi siswa. Penulis memberikan motivasi kepada siswa bahwa pekerjaan mereka akan dinilai dan disetorkan kepada guru yang bersangkutan.

Setelah kegiatan awal selesai selanjutnya penulis melakukan kegiatan inti pembelajaran. Dalam kegiatan ini penulis terlebih dahulu menunjuk perwakilan dari setiap kelompok siswa yang akan menjadi tutor bagi temannya. Setelah penulis menetapkan beberapa siswa yang menjadi tutor, penulis menjelaskan cara pembelajaran dengan model tutorial ini. Awalnya siswa masih bingung dengan model pembelajaran tutorial ini, namun setelah penulis jelaskan bahwa tutor itu adalah wakil penulis yang penulis anggap telah mampu menulis surat dinas untuk membimbing teman-temanya yang belum mampu menulis surat dinas. Dengan penjelasan seperti itu akhirnya siswa mengerti tentang tugas tutor.

Dalam pelaksanaan ini penulis kembali memberikan berkas materi tentang surat dinas kepada setiap tutor dan satu buah contoh surat dinas. Pelaksanaan 
kegiatan seperti ini ternyata membuat siswa semakin aktif dalam melaksanakan kegiatan karena mungkin mereka merasa tidak canggung untuk menanyakan hal yang kurang dipahaminya karena tutornya adalah temannya sendiri. Para siswa tampak antusias dan yang menjadi tutor pun antusias untuk menjelaskan dan memberi bimbingan kepada temantemannya. Dalamn proses ini terjadi diskusi yang baik dalam setiap kelompok.

Langkah selanjutnya, setiap siswa harus membuat surat dinas yang berisi tentang surat permohonan izin kegiatan. Dalam proses penulisan surat ini tutor terus berperan dengan cara memberikan pengarahan kepada tutee atau siswa yang ditutorinya. Setelah semua siswa selesai membuat surat dinas, penulis menyuruh perwakilan tiap kelompok membacakan surat dinas yang ditulisnya dan kelompok lain memberi komentar, saran, atau kritiknya terhadap surat dinas yang telah dibaca. Selama kegiatan inti ini berlangsung penulis melaksanakan penilaian proses mpembelajaran.

Setelah kegiatan inti selesai dilaksanakan, kegiatan selanjutnya yaitu kegiatan akhir yakni kegiatan menyimpulkan materi yang telah dipelajari. Proses pembuatan simpulan ini dilaksanakan secara bersama-sama dengan siswa. Pada tahap refleksi penulis menelaah kembali pelaksanaan proses pembelajaran yang telah dilaksanakan untuk menemukan kelemahan dan keunggulan peroses pembelajaran yang telah dilaksanakan dengan melibatkan siswa. Setelah proses pembelajaran berakhir penulis mengecek kemampuan siswa dalam menulis surat dinas dengan cara mengumpulkan hasil kerja siswa kepada penulis sebagai bahan penilaian hasil belajar.

\section{Review/Balikan}

Pada kegiatan ini dilaksanakn refleksi pelaksanaan kegiatan tutorial yang sudah dilaksanakan.
Pada tahap ini penulis kembali menguatkan hal-hal yang sudah baik dan harus tetap dipertahankan dan hal-hal yang kurang yang harus diperbaiki. Penulisan juga menjelaskan kembali tuju $\mathrm{n}$ dari setiap tahapan tutorial tersebut. Diakhir kegiatan semua siswa melaksanakn test individu untuk menguji kemampuan siswa secaar individu.

\section{Hasil Observasi dan Evaluasi}

\section{Pelaksanaan Pembelajaran Tutorial}

Data hasil observasi tentang pelaksanaan pembelajaran tutorial dapat dilihat pada tabel 4 di bawah ini.

Tabel 4. Hasil Observasi Pelaksanaan Pembelajaran Tutorial

\begin{tabular}{cc}
\hline $\begin{array}{c}\text { Penentu } \\
\text { Keberhasilan } \\
\text { Tindakan }\end{array}$ & $\begin{array}{c}\text { Rerata Skor } \\
\text { Pelaksanaan } \\
\text { Pembelajaran }\end{array}$ \\
\hline Langkah 1 & 4 \\
\hline Langkah 2 & 3,5 \\
\hline Langkah 3 & 4 \\
\hline Rata-Rata & 3,65 \\
\hline Rata-Rata dalam \% & $95,8 \%$ \\
\hline
\end{tabular}

Berdasarkan skor data pelaksanaan pembelajaran tutorial diperoleh rata-rata persentase pelaksanaan pembelajaran pada siklus II sebesar 95,8\%. Hal ini menunjukkan bahwa pada setia tahapan pembelajarn sudah dilaksanakan dengan maksimal di antaranya: 1) pada tahap persiapan, siswa sudah terbiasa melaksanakan pembelajaran dengan model tutorial, penentuan tutor tidak membutuhkan waktu lama, 2) pada kegiatan pelaksanaan tindakan tutor sudah terlihat percaya diri dan mampu menggali kemampuan temannya yang ditutori melalui diskusi yang semain aktif,. 3) pada kegiatan penutup review/balikan dapat dilaksanakan dengan cukup leluasa dengan sisa waktu yang ada.

\section{Proses pembelajaran siswa}

Selama proses pembelajaran penulis juga mengamati perlaku siswa selama mengikuti pembelajaran tersebut. Dari hasil pengamatan terhadap sikap siswa selama mengikuti proses 
pembelajaran didapatkan data dalam tabel 5 di bawah ini.

Tabel 5. Rata-rata Skor \& Prosentase Hasil Observasi Proses Pembelajaran Siswa

\begin{tabular}{cccc}
\hline & Skor & $\begin{array}{c}\text { Prosentase } \\
(\%)\end{array}$ & Kategori \\
\hline Keaktifan & 3,65 & 91,13 & $\begin{array}{c}\text { Sangat } \\
\text { Baik }\end{array}$ \\
\hline Bekerja sama & 3,84 & 95,97 & $\begin{array}{c}\text { Sangat } \\
\text { Baik }\end{array}$ \\
\hline Kesungguhan & 3,61 & 90,32 & $\begin{array}{c}\text { Sangat } \\
\text { Baik }\end{array}$ \\
\hline Partisipasi & 3,32 & 83,06 & $\begin{array}{c}\text { Sangat } \\
\text { Baik }\end{array}$ \\
\hline
\end{tabular}

Berdasarkan tabel 5 di atas, dari keempat aspek sikap siswa yang diamati. Pada aspek keaktifan diperoleh skor ratarata 3,65 atau 91,13 dengan katagori sangat baik. Artinya selama mengikuti pembelajaran dengan tutorial siswa secara keseluruhan sudah menunjukkan keaktifan yang sangat baik. Pada aspek kerja sama diperoleh skor 3,84 aatau 95,97 dengan katagori sangat baik. Artinya dengan pembelajaran tutorial para siswa selama proses pembelajaran bekerja sama dengan sangat baik. Pada aspek kesungguhan diperoleh nilai rata-rata 3,61 atau 90,32 dengan kategori sangat baik, artinya peseta didik sudah tampak sikap kesungguhan selama mengikuti proses pembelajaran. Pada tahap partisipasi diperoleh nilai rata-rata skor 3,32 atau 83,06 dengan kategori baik, artinya partsipasi siswa dalam belajar dengan model tutorial menunjukkan partsipasi yang baik.

\section{Kemampuan menulis surat dinas}

Kemampuan menulis surat dinas pada siklus kedua ini dilihat dari hasil kerja siswa dalam menulis surat dinas setelah mereka mengikuti pembelajaran dengan model tutorial. Dari hasil analisis data pekerjaaan siswa dalam menulis surat dina dieproleh data sebagai berikut.

Tabel 6. Nilai Kemampuan Menulis Surat Dinas Siswa pada Siklus II

\begin{tabular}{|c|c|c|c|c|}
\hline No & Kategori & $\begin{array}{c}\text { Rentang } \\
\text { Skor }\end{array}$ & $\begin{array}{c}\text { Jumlah } \\
\text { Siswa }\end{array}$ & $\begin{array}{c}\text { No } \\
\text { Absen }\end{array}$ \\
\hline
\end{tabular}

\begin{tabular}{|c|c|c|c|c|}
\hline 1 & $\begin{array}{c}\text { Sangat } \\
\text { Baik }\end{array}$ & $80-100$ & 24 & \\
\hline 2 & Baik & $70-79$ & 7 & \\
\hline 3 & Cukup & $60-69$ & 0 & \\
\hline 4 & Kurang & $50-59$ & 0 & \\
\hline 5 & $\begin{array}{c}\text { Sangat } \\
\text { Kurang }\end{array}$ & $<50$ & 0 & \\
\hline
\end{tabular}

Berdasarkan tebal 3 di atas, diketahui bahwa katergori nilai siswa semua ada direng baik dan sangat baik. 24 orang pada rentang sangat baik dan 7 orang pada siswa yang memperoleh nilai dalam kategori sangat baik sebanyak 24 orang dan 7 orang dengan kategori baik.

\section{Refleksi}

Berdasarkan data pada kedua tabel di atas, diketahui siswa sudah mampu menulis surat dinas sesuai dengan kriteria. Surat yang ditulis oleh siswa sudah memenuhi kelengkapan struktur, ketepatan isi, bahasa yang baku, dan penggunaan ejaan yang sudah tepat. Namun sebagian kecil masih ada juga siswa yang belum tepat dalam menulis surat dinas terutama dalam penggunaan ejaan. Meskipun demikian hasil dari siklus dua ini cukup memuaskan.

Secara ringkas hasil refleksi dinyatakan sebagai berikut.

1. Siswa sudah mengerti akan pentingnya surat dinas dalam kegiatan sekolah.

2. Siswa sudah mampu menulis surat dinas dengan baik.

3. Belum semua siswa mampu menggunakan ejaan dengan baik.

Atas dasar refleksi tersebut penulis berkesimpulan hasil dari siklus dua memuaskan, siswa sudah mampu menulis surat dinas dengan baik.

\section{KESIMPULAN}

Setelah penulis menyelesaikan penelitian ini, penulis dapat menyimpulkan hasil penelitian ini. Model pembelajaran tutorial dapat meningkatkan hasil pembelajaran menulis surat dinas pada siswa kelas VIII SMP Negeri 1 Puspahiang. Hal ini dapat dilihat dari 
peningkatan nilai hasil belajar dan proses belajar dari siklus I ke siklus II.

Dalam kesempatan ini penulis mencoba menyampaikan beberapa saran yang terkait dengan penelitian ini.

1. Guru bahasa Indonesia hendaknya selalu inovatif dalam penentuan model-model pembelajaran yang aktual.

2. Sebaiknya guru selalu memotivasi siswa dalam proses pembelajaran di dalam kelas dengan cara-cara inovatif.

3. Sebaiknya guru mengembangkan wawasan dan potensi dirinya yang berkaitan dengan tuntutan profesi keguruannya.

4. Sebaiknya sekolah juga berperan sebagai pengembang minat dan bakat siswa dalam menulis.

5. Agar siswa senang menulis, sebaiknya guru memberi contoh kepada siswa dengan menghasilkan karya tulis.

6. Sebaiknya koleksi buku-buku perpustakaan sekolah harus diperhatikan kelengkapan dan keanekaragamannya.

7. Untuk kemajuan prestasi belajar siswa, sebaiknya sekolah bekerja sana dengan orang tua siswa untuk saling membimbing anak didiknya untuk lebih berprestasi dalam semua bidang studi.

\section{DAFTAR PUSTAKA}

Abidin, Y. (2006). Terampil Menulis Karya Ilmiah di Perguruan Tinggi. Tasikmalaya: HZAA Pres.

Anggorowati, N.P. (2011). Penerapan Model Tutor Sebaya pada Mata Pelajaran Sosiologi. Jurnal Komunitas 3(1) (2011): 103-120.

Arikunto, S. (2007). Penelitian Tindakan Kelas. Jakarta: Bumi Aksara.

Heryadi, D. (2014). Metode Penelitian Pendidikan Bahasa. Bandung: Pusbill

Kemal, I. (2013). Kemampuan Menulis Surat Dinas. Jurnal Metamorfosa, 1(1), pp. 1-10.

Kosasih, E. (2003). Surat Menyurat dan Menulis Surat Dinas Dengan Benar. Bandung: Yrama Widya.

Marjo, Y. S. (2000). Surat-surat Lengkap. Jakarta: Setia Kawan.

Sabariyanto, Dirgo. (1998). Bahasa Surat Dinas. Yoyakarta: Mitra Gama Widya.

Winataputra. (1997). Model-Model Pembelajaran Interaktif. Jakarta: PT Repro International. 